\title{
CONTROLE DE QUALIDADE DE PROTEÍNA NA DISFUNÇÃOIATROFIA MUSCULAR ESQUELÉTICA: PAPEL DO RECEPTOR $\beta_{2}$-ADRENÉRGICO
}

Tese apresentada ao Programa de PósGraduação em Ciências Morfofuncionais do Instituto de Ciências Biomédicas da Universidade de São Paulo, para obtenção do Título de Doutor em Ciências

Área de concentração: Ciências Morfofuncionais

Orientador: Prof. Dr. Julio Cesar Batista Ferreira

Versão original. 


\section{RESUMO}

Campos, JC. Controle de qualidade de proteína na disfunção/atrofia muscular esquelética: papel do receptor $\beta_{2}$-adrenérgico. [Tese (Doutorado em Ciências Morfofuncionais)]. São Paulo; Instituto de Ciências Biomédicas, Universidade de São Paulo; 2017.

A disfunção/atrofia muscular esquelética é quadro resultante de diversos processos degenerativos. A hiperativação dos sistemas de degradação proteica [ubiquitina-proteassoma e lisossomal-autofágico (autofagia)] é comumente apontada como o principal desencadeador desse quadro. Contudo, esses sistemas também integram um especializada maquinaria de controle de qualidade de proteína (CQP), cuja função abrange o monitoramento e a proteção contra o acúmulo de proteínas/organelas não-funcionais, visando a manutenção da viabilidade celular. Nesse contexto, inicialmente caracterizamos o CQP em modelo de disfunção/atrofia muscular induzida por constrição crônica do nervo isquiático $(\mathrm{CCl})$ em ratos. 14 dias após $\mathrm{CCl}$ constatamos uma atrofia muscular de 50\%, acompanhada de uma drástica redução na força tetânica quando comparada aos animais Controle. Ainda, o aumento da atividade catalítica, tanto proteassomal, quanto autofágica, não foi capaz de prevenir o acúmulo de proteínas citotóxicas (oligômeros solúveis, poliubiquitinadas e carboniladas) na musculatura atrófica desses animais, quadro associado à ativação da via apoptótica. Esses dados indicam um prejuízo no CQP na disfunção/atrofia muscular. Na sequência, optamos por manipular o CQP. Recentemente foi demonstrado que a fosforilação/ativação do proteassoma, decorrente da ativação $\beta$-adrenérgica ( $\beta-A R)$, resulta na melhora do CQP e aumento da viabilidade no músculo cardíaco. Baseado nesses resultados, e sabendo que a sinalização $\beta$-AR destaca-se por seu papel protetor na morfologia/fisiologia muscular esquelética, decidimos verificar o efeito da estimulação $\beta$-AR na regulação do CQP. 14 dias de tratamento com Formoterol (agonista do receptor $\beta$-AR, subtipo $\beta_{2}-10$ $\mu \mathrm{g} \cdot \mathrm{kg}^{-1} \cdot \mathrm{dia}^{-1}$ ) foram capazes de atenuar a disfunção/atrofia muscular e promover um aumento adicional na atividade proteassomal, bem como restaurar o fluxo de degradação via autofagia, em relação ao grupo $\mathrm{CCl}$ tratado com salina. Esse fenótipo culminou na redução dos níveis de proteínas citotóxicas e de proteínas relacionadas à apoptose, sugerindo uma melhora global do CQP após estimulação $\beta_{2}-A R$ na musculatura esquelética. Cabe salientar que o tratamento com uma dose não-hipertrófica de Formoterol $\left(1 \mu \mathrm{g} \cdot \mathrm{kg}^{-1} \cdot \mathrm{dia}^{-1}\right)$ também resultou na melhora do CQP e da função muscular, porém em menor magnitude. De forma intrigante, observamos que a inibição da autofagia (Cloroquina $50 \mathrm{mg} \cdot \mathrm{kg}^{-1} \cdot \mathrm{dia}^{-1}$ ), mas não do proteassoma (Bortezomibe $0,2 \mathrm{mg} \cdot \mathrm{kg}^{-1}$ ), foi capaz de abolir os efeitos benéficos da ativação $\beta_{2}-\mathrm{AR}$ na disfunção/atrofia muscular. Por fim, a ativação $\beta_{2}-A R$ teve efeito positivo na função e biogênese mitocondrial, tanto em músculo de ratos, como em miotúbulos em cultura. A melhora nos processos de fusão-fissão mitocondrial e de degradação da organela (mitofagia) - componentes do controle de qualidade mitocondrial (CQM), parece ter contribuído para essa resposta. Em conjunto, nossos resultados sugerem uma nova contribuição da via de sinalização $\beta_{2}$-AR no quadro de disfunção/atrofia muscular esquelética, no qual a ativação do receptor $\beta_{2}-A R$ foi capaz de restaurar o insuficiente CQP, contribuindo para a melhora do trofismo e função muscular. Além disso, nossos dados evidenciam o papel da ativação $\beta_{2}$-AR 
no CQM e reforçam a importância da autofagia como um modulador da morfologia/fisiologia muscular esquelética.

Palavras-chave: Músculo esquelético. Receptor adrenérgico. Controle de qualidade de proteína. Autofagia. Proteassoma. 


\begin{abstract}
Campos, JC. Protein quality control in skeletal muscle weakness/wasting: role of $\beta_{2^{-}}$ adrenoceptor. Ph.D. Thesis [(Morphofunctional Sciences)]. São Paulo; Instituto de Ciências Biomédicas, Universidade de São Paulo; 2017.

Sustained loss of skeletal muscle mass and function occurs mainly during degenerative processes. Increased proteolytic activity (i.e. ubiquitin-proteasome system and autophagy) has been extensively associated with muscle atrophy; however, proteolysis is also crucial for the maintenance of cellular homeostasis. In fact, these degradation systems play an important role in the protein quality control (PQC) machinery, a process that can detect, repair and dispose cytotoxic proteins and non-functioning organelles. In this context, we first assessed PQC in a rat model of skeletal muscle weakness/wasting induced by a permanent sciatic nerve constriction (SNC). SNC rats present a drastic reduction in both skeletal muscle mass $(55 \%)$ and contractile properties (92\%) compared to Control group at day 14 after surgery. Of interest, $\mathrm{PQC}$ is disrupted in SNC rats, demonstrated by elevated proteasomal and lysosomal activities along with accumulation of cytotoxic proteins (misfolded, polyubiquitinated and carbonylated) and pro-apoptotic factors. We next tested whether modulating PQC could affect the skeletal muscle pathophysiology. It was recently demonstrated that $\beta$-adrenoceptor ( $\beta-A R)$ signaling pathway is able to improve $P Q C$ by phosphorylating proteasome in heart, therefore increasing cellular viability. Thus, we decided to investigate the role of $\beta-A R$ (subtype $\beta_{2}$ ) in regulating $P Q C$ in skeletal muscle weakness/wasting. Our findings demonstrate that $\beta_{2}-A R$ activation (Formoterol $10 \mu \mathrm{g} \cdot \mathrm{kg}^{-1}$. day ${ }^{-1}$ ) promotes a further increase in proteasomal activity, along with autophagic flux reestablishment, compared to SNC placebotreated animals. These changes are followed by reduction of cytotoxic protein levels, increase in muscle mass and better ex vivo function. Of interest, sustained autophagy inhibition using Chloroquine (50 mg. $\mathrm{kg}^{-1}$.day ${ }^{-1}$ ) over 14 days, but not proteasomal inhibition (Bortezomib, $0.2 \mathrm{mg} \cdot \mathrm{kg}^{-1}$.day ${ }^{-1}$ ), is sufficient to abolish in vivo $\beta_{2}$-AR agonist effects on skeletal muscle PQC, mass and strength. Finally, $\beta_{2}-A R$ activation has a positive effect on mitochondrial density and oxidative capacity in both rat skeletal muscle and myotubes in culture. These changes seem to be triggered by improved mitochondrial quality control (MQC, i.e. fusion-fission processes and degradation through mitophagy). Altogether, these findings suggest a new contribution of $\beta_{2}$-AR signalling pathway to the pathophysiology of skeletal muscle where $\beta_{2}$-AR restores the impaired PQC, therefore contributing to a better skeletal muscle morphology and function. These findings also suggest the role of $\beta_{2}-$ AR on MQC and highlight autophagy as a modulator of skeletal muscle properties.
\end{abstract}

Keywords: Skeletal muscle. Adrenoceptor. Protein quality control. Autophagy. Proteasome. 


\section{INTRODUÇÃO}

A atrofia muscular esquelética, caracterizada pela redução da massa muscular e consequente diminuição de sua capacidade contrátil, é ponto convergente da maioria das doenças musculoesqueléticas, além de ser um importante determinante da classe funcional e prognóstico de pacientes em outras patologias como câncer, sepse e cardiomiopatias (1). Com o crescente aumento da expectativa média de vida, estima-se ainda que distúrbios musculares estarão presentes em $\sim 20 \%$ do tempo de vida de cada indivíduo (2). Levando em consideração a importância da musculatura apendicular para a autonomia e qualidade de vida, a investigação das alterações morfológicas, funcionais e metabólicas no tecido muscular esquelético vem ganhando destaque na comunidade científica.

Os mecanismos que desencadeiam a atrofia muscular permanecem em constante debate na literatura. Descrita inicialmente como uma mudança estrutural oriunda apenas do desequilíbrio entre a síntese e a degradação proteica, hoje sabese que a instalação e a progressão da atrofia muscular também vem acompanhada de prejuízos no metabolismo energético e na homeostase redox; fatores que culminam na redução da viabilidade e até mesmo morte do miócito esquelético (3). Nesse contexto, dois sistemas proteolíticos dependentes de ATP (trifosfato de adenosina) tem ganhado destaque: o sistema ubiquitina-proteassoma (SUP) e o sistema lisossomal-autofágico.

O SUP degrada predominantemente proteínas miofibrilares, ao passo que o sistema lisossomal-autofágico é responsável pela remoção de organelas nãofuncionais e de agregados proteicos. Em conjunto, a hiperativação desses sistemas vem sendo reportada como o grande vilão do quadro de disfunção/atrofia muscular $(4,5)$. Entretanto, eles também são parte fundamental de um refinado processo de controle de qualidade de proteína (CQP), cuja principal função reside no monitoramento e proteção da célula contra o acúmulo de proteínas e organelas danificadas (6). Vale destacar que o papel do SUP e do sistema lisossomalautofágico no CQP muscular, bem como seu efeito na morfologia e viabilidade do miócito ainda é incipiente.

Além disso, devido ao papel crucial da mitocôndria no âmbito energético e na viabilidade celular, a participação dessa organela se torna cada vez mais evidente 
na regulação do trofismo muscular (7). Antes considerada uma organela estática, atualmente a mitocôndria é reconhecida por sua dinâmica intracelular. De fato, na tentativa de se adequar à demanda metabólica, a mitocôndria acaba por modificar sua forma, número e distribuição ao longo da célula. Esses ajustes são controlados por processos altamente especializados que, em conjunto, estão no comando do controle de qualidade mitocondrial (CQM) (8), podendo impactar diretamente na fisiologia muscular esquelética (9).

Dentre os principais moduladores do trofismo/função muscular esquelética, destaca-se a sinalização $\beta$-adrenérgica ( $\beta$-AR), com ênfase para a cascata de reações desencadeada pelo receptor do subtipo $\beta_{2}$. A promoção do anabolismo e a inibição de vias catabólicas, resultando em hipertrofia muscular, estão entre as principais respostas benéficas promovidas por agonistas do receptor $\beta_{2}-A R$; contudo, os mecanismos moleculares envolvidos nesse quadro ainda não foram totalmente elucidados (10). Considerando o exposto acima, uma das possíveis explicações envolve o efeito positivo da estimulação $\beta-A R$ na biogênese mitocondrial (11).

Ainda, recentemente foi demonstrada a influência desse receptor na modulação do CQP no músculo cardíaco. De fato, evidências sugerem que alterações pós-traducionais do proteassoma induzidas pela PKA (protein kinase A parte da via canônica de sinalização $\beta-A R$ ), são capazes de aumentar a atividade proteolítica desse complexo, resultando em melhora do CQP e aumento da viabilidade do cardiomiócito $(12,13)$. No entanto, não se sabe ao certo o papel e a consequência dessas interações na musculatura esquelética.

Devido à relevância e implicação clínica da disfunção/atrofia muscular, compreender os mecanismos celulares que regulam as características morfofuncionais do tecido muscular esquelético é fator crucial para o desenvolvimento de terapias tanto farmacológicas, quanto não farmacológicas capazes de atenuar os distúrbios musculares. Sendo assim, o presente estudo teve como propósito avaliar o papel do CQP na regulação do trofismo e função muscular em modelo animal de disfunção/atrofia muscular induzida por constrição crônica do nervo isquiático $(\mathrm{CCl})$, bem como a investigação dos possíveis mecanismos intracelulares envolvidos nessa modulação após estimulação do receptor $\beta_{2}-A R$. 


\section{REVISÃO DE LITERATURA}

\subsection{DISFUNÇÃO/ATROFIA MUSCULAR ESQUELÉTICA}

Representando cerca de $40 \%$ da massa corporal e apresentando ampla variação entre indivíduos da mesma espécie, a musculatura esquelética tem recebido merecida atenção na literatura científica desde a década de 1960 (14). Ao longo dos últimos 20 anos o conceito sobre o músculo esquelético foi revisto e substituído. Antes definido como um tecido periférico inerte, atualmente a musculatura esquelética é reconhecida por sua plasticidade frente a diferentes estímulos e demandas, onde a massa e o metabolismo muscular são diretamente modulados por exigências energéticas e contráteis (15).

A manutenção da massa muscular é determinada pela razão síntese/degradação proteica. Valores acima e abaixo de 1 refletem estados hipertróficos e atróficos, respectivamente (16). A atrofia muscular, caracterizada pela diminuição da área da secção transversa (AST) das fibras musculares, é quadro resultante em diversas condições patológicas tais como câncer (17), doenças cardiovasculares (18), sepse (19), doença renal crônica (20) e distrofias musculares (21). Além disso, outros eventos também são capazes de desencadear a atrofia muscular dentro de uma janela temporal mais curta quando comparados aos acometimentos crônicos. De fato, imobilizações decorrentes de fratura óssea (22), lesões nervosas (23) e exposição a ambientes com baixa tensão gravitacional (24) são exemplos de situações que invariavelmente levam à perda de tecido muscular esquelético após poucas semanas. Apesar de não ser o único fator determinante, o quadro atrófico leva ao enfraquecimento dos membros afetados e limitação na realização de movimentos; podendo contribuir para a redução da qualidade de vida. Ainda, mesmo com a disparidade de etiologias e modelos experimentais utilizados, parece haver um consenso de que a atrofia muscular é um importante agravante do quadro clínico de pacientes, sendo um preditor da gravidade e classe funcional de doenças (25).

Do ponto de vista estrutural, a atrofia muscular pode ser resultado de: (a) uma redução da síntese proteica, (b) um aumento no processo de degradação ou ainda (c) uma combinação de ambos (3). Nesse sentido, a ciência contemporânea busca entender os diferentes mecanismos celulares envolvidos na regulação do trofismo 
muscular esquelético com o intuito de identificar potenciais alvos terapêuticos no combate à degeneração muscular. Dentre os mais estudados, destacam-se a via de sinalização IGF-1/Akt/mTOR, importante na sinalização nuclear para síntese proteica (26) e o SUP, responsável pela degradação de grande parte das proteínas intracelulares e aparentemente hiperativado em estados atróficos (4). Cabe salientar que o SUP será melhor discutido no decorrer deste trabalho. Considerando esses achados, parte importante do presente estudo consistiu na caracterização morfofuncional da musculatura esquelética nos diferentes grupos estudados.

O IGF-1 (insulin-like growth factor 1) é fundamental na homeostase muscular pois, além de regular a proliferação e diferenciação, também está envolvido no crescimento e sobrevivência do miócito esquelético. Conforme ilustração ao lado, o aumento da síntese proteica se dá por sua ligação ao receptor IRS-1 (insulinlike receptor 1) desencadeando a ativação da Akt (protein kinase $B$ ), cujo principal alvo é a mTOR (mechanistic target of rapamycin). A mTOR regula a síntese proteica por meio das proteínas S6K1 (P70 ribosomal S6 kinase 1) e $4 E B P 1$ (eukaryotic initiation factor $4 E$ [elF4E] binding protein 1); que, em conjunto com outras proteínas, são

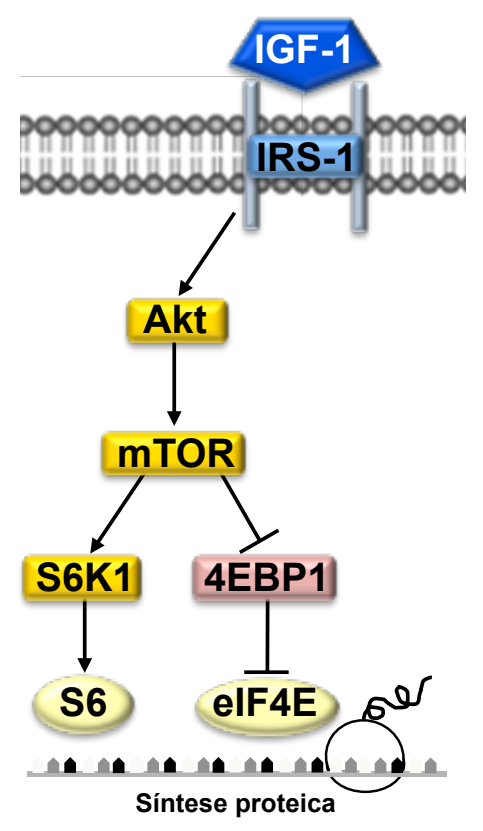
responsáveis pela iniciação, elongamento e terminação do RNA mensageiro (27). Cabe salientar que a sinalização de mTOR também é regulada pelo status energético da célula. A AMPK (adenosine monophosphate-activated protein kinase) - importante sensor do quadro energético celular, é capaz de inibir vias anabólicas em paralelo à estimulação de vias de catabolismo, na tentativa de promover a homeostase energética (28).

A instalação e progressão da disfunção/atrofia muscular esquelética abrangem, além da mudança estrutural, alterações em mecanismos intracelulares com destaque para o metabolismo energético, o estresse oxidativo e a morte celular programada - apoptose. De fato, a redução da capacidade oxidativa mitocondrial com consequente impacto na depleção de ATP e na produção exacerbada de espécies reativas de oxigênio (EROs), acompanha a atrofia muscular tanto no envelhecimento, quanto em modelos experimentais de desuso e denervação (23, 29). Nesse sentido, grande atenção é voltada à alteração da homeostase redox na 
musculatura esquelética, no qual o ambiente pró-oxidante induz disfunção dos miofilamentos contráteis (30) e antecipação da fadiga (31), além de acelerar o processo de atrofia muscular observado no envelhecimento e em algumas patologias (32). Por fim, a literatura também aponta a morte celular necrótica como contribuinte para a atrofia muscular (33). Apesar dos mecanismos ainda não estarem totalmente elucidados, o quadro atrófico parece também ser agravado pela perda progressiva de mionúcleos por apoptose (34).

\subsection{CONTROLE DE QUALIDADE DE PROTEÍNA (CQP)}

O CQP consiste na supervisão e no processamento de proteínas malformadas ou danificadas. Esse tipo de controle celular é bastante estudado em doenças neurodegenerativas e em doenças cardiovasculares, onde alterações genéticas (mutações), modificações pós-traducionais e EROs acarretam na perda da conformação nativa e função da proteína, com consequente acúmulo de proteínas danificadas e degeneração do tecido $(35,36)$. Na tentativa de evitar o acúmulo dessas proteínas citotóxicas, sistemas de proteção envolvidos no CQP são ativados, dentre eles destacam-se as chaperonas, o SUP e o sistema lisossomal-autofágico. O primeiro auxilia no enovelamento das proteínas danificadas, o segundo é responsável por mais de $80 \%$ da degradação de proteínas intracelulares e o terceiro promove a degradação tanto de agregados proteicos, quanto de organelas. Trabalhando em conjunto, esses sistemas evitam os efeitos citotóxicos desencadeados pelo acúmulo de ambos, proteínas danificadas e organelas disfuncionais $(6,36)$.

Com o intuito de manter a homeostase celular, chaperonas são recrutadas

para assistir o enovelamento de proteínas, prevenir a agregação proteica e promover a reestruturação (reenovelamento) de proteínas desnaturadas. Em conjunto com a biogênese, o transporte e a degradação de proteínas, essas pequenas moléculas formam a primeira linha de defesa para garantir a proteostase (homeostase proteica) da célula (37). O SUP e o sistema lisossomal-autofágico estão melhor descritos nas subseções a seguir.

Devido à importância do CQP na manutenção da viabilidade celular, este passou a ser um importante alvo de estudos na última década. Vale destacar que o aumento de proteínas danificadas é descrito como um dos principais 
desencadeadores da morte celular em diferentes doenças (38-40). Nesse contexto, a manutenção da integridade e funcionalidade mitocondrial passa a ser crítica para a fisiologia da musculatura esquelética. De fato, uma vez que essa organela tem papel fundamental na regulação da homeostase intracelular, participando desde o suprimento energético até a morte celular programada, as células eucarióticas desenvolveram mecanismos refinados que controlam tanto a forma quanto a função mitocondrial (CQM) (41). Informações mais detalhadas sobre o CQM se encontram apresentadas a seguir.

\subsubsection{Sistema ubiquitina-proteassoma (SUP)}

O SUP, comumente descrito como a segunda linha de defesa do CQP, representa o maior sistema proteolítico intracelular responsável pela degradação de proteínas oxidadas e poliubiquitinadas. Esse refinado sistema catabólico consiste numa sequência de reações enzimáticas responsáveis pela seleção, marcação e degradação da proteína alvo conforme representado na Figura 1. As enzimas conhecidas como "E-ligases", a proteína ubiquitina e o core multicatalítico proteassomal, além de ATP, são essenciais para esse processo. De maneira simplificada, a proteína ubiquitina (que funciona como uma etiqueta de marcação) é inicialmente ativada pela ligase E1 numa reação dependente de ATP. Essa ubiquitina ativada é então transferida para a ligase E2 que promove a conjugação de várias ubiquitinas formando uma cauda de poliubiquitinas. Na sequência, a ligase E3 transfere essa cauda de poliubiquitinas para a proteína alvo a ser degradada. Por fim, a proteína alvo marcada com a cauda de poliubiquitinas é reconhecida e degradada pelo proteassoma em pequenos peptídeos (42). Ainda, uma classe de enzimas denominadas deubiquitinases regulam a remoção das ubiquitinas das proteínas alvo, permitindo assim a reciclagem dessas moléculas marcadoras (43).

Em geral, o complexo proteassomal é composto por duas subunidades distintas, a porção regulatória $19 S$ e a porção catalítica 20S, formando o proteassoma 26S. A primeira é responsável pelo reconhecimento e desenovelamento da proteína alvo num processo dependente de ATP, ao passo que a atividade de degradação ocorre na segunda porção por meio de três sítios catalíticos: $\beta 1$ - cliva ligações peptídicas após resíduos ácidos (caspase-like), $\beta 2$ cliva ligações peptídicas após resíduos básicos (trypsin-like) e $\beta 5$ - cliva ligações 
peptídicas após resíduos hidrofóbicos (chymotrypsin-like) (44). Vale destacar que a degradação proteassomal também ocorre de forma independente da ubiquitinação e do dispêndio energético. De fato, proteínas estruturalmente modificadas devido à oxidação, mutação ou envelhecimento; bem como proteínas nascentes malenoveladas, podem ser degradadas diretamente pelo core 20S. Contudo, ainda não foi descrito como a proteólise mediada pelo $20 \mathrm{~S}$ é controlada (45).

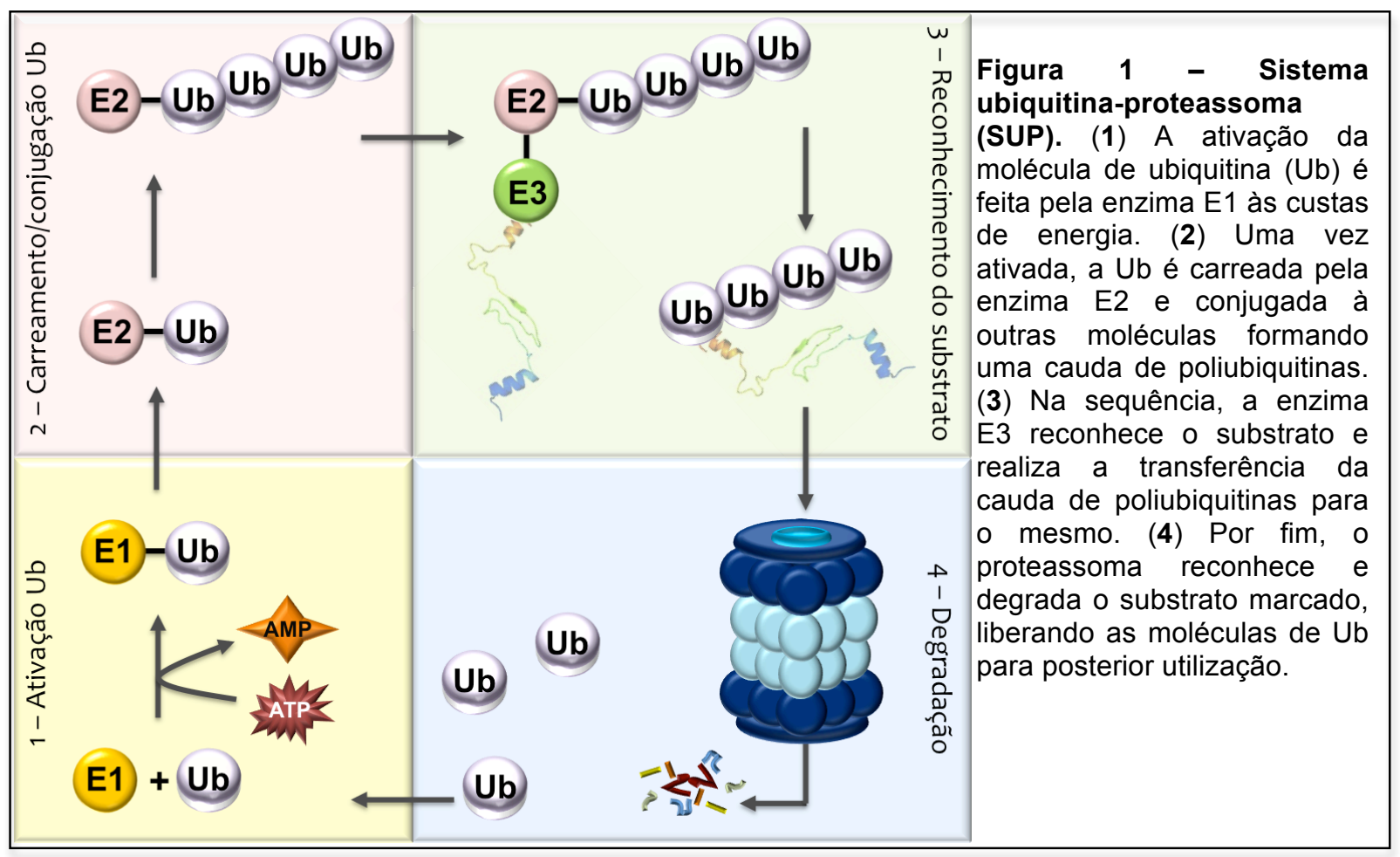

Nas últimas décadas, estudos vem demonstrando que o SUP se encontra hiperativado em quadros catabólico, sugerindo que essa exacerbada atividade catalítica é responsável pela indução da fraqueza e atrofia muscular. Nesse contexto, a inibição proteassomal tem sido proposta como terapia no combate à perda de massa muscular, tanto em humanos como em modelos animais (46-48). Contudo, mesmo atenuando a proteólise e a consequente perda de massa muscular, a inibição sustentada do SUP não foi capaz de prevenir a perda de força muscular em alguns casos (49). Além disso, células musculares tratadas com um inibidor da atividade proteassomal apresentaram um acúmulo de proteínas poliubiquitinadas seguida de morte celular $(47,50)$.

Por outro lado, um acúmulo de proteínas poliubiquitinadas em diferentes quadros de disfunção/atrofia muscular tem sido constatado, mesmo com o aumento 
na atividade do SUP $(47,51-53)$, fato que sugere uma ineficiência do sistema catalítico na remoção de proteínas citotóxicas. Apesar de alterações no SUP já terem sido descritas na musculatura esquelética atrófica, pouco se sabe sobre os mecanismos celulares responsáveis pela inibição ou ativação do CQP, bem como sua contribuição para a geração de força pela célula muscular esquelética.

Por fim, foi demonstrado na última década que alterações pós-traducionais como oxidação, fosforilação e acetilação do proteassoma estão diretamente envolvidas na regulação do CQP (54). Dentre eles, a fosforilação do proteassoma cardíaco pela PKA nos chamou a atenção, visto que além de aumentar a atividade catalítica do complexo, também resultou em melhora do CQP e viabilidade celular no coração de cães submetidos à isquemia $(12,13)$. No entanto, não se sabe ao certo o papel e a consequência dessas interações na musculatura esquelética. Sabendo que a PKA é uma proteína-chave envolvida na sinalização celular mediada pelos receptores $\beta-A R$ na musculatura esquelética, investigamos nesse estudo se a estimulação $\beta_{2}$-AR poderia exercer papel na regulação do SUP e, consequentemente, no CQP na disfunção/atrofia muscular.

\subsubsection{Sistema lisossomal-autofágico (autofagia)}

Descrito há 52 anos pelo ganhador do prêmio Nobel Christian De Duve (55), o sistema lisossomal-autofágico compreende a terceira linha de defesa do CQP. Conservado evolutivamente em células eucarióticas, o mecanismo catabólico denominado autofagia - do grego: autos, próprio e phagin, comer, envolve o transporte de estruturas e componentes citoplasmáticos para serem degradados pelo lisossomo. Dependendo da estrutura/componente a ser degradado, esse processo pode ocorrer por diferentes formas: a) autofagia mediada por chaperonas: na qual essas pequenas moléculas reconhecem o substrato, o encaminhando diretamente ao lisossomo; b) microautofagia: processo cuja invaginação da própria membrana lisossomal envolve porções citoplasmáticas que serão degradadas pelas hidrolases ácidas e c) macroautofagia: englobamento de estruturas (incluindo organelas) citoplasmáticas pelo autofagossomo - dupla membrana lipídica que posteriormente se fundirá com o lisossomo liberando seu conteúdo para degradação no interior da organela (56-58). 
A degradação lisossomal via macroautofagia é o processo mais estudado atualmente, sendo comumente reportado simplesmente como autofagia. Ao todo já foram descritos mais de 30 genes envolvidos nesse processo, com destaque para a família Atg (autophagy-related), que por meio de uma sequência de reações enzimáticas similar ao SUP promove a iniciação e o elongamento do fagoforo (uma membrana de isolamento que dará origem ao autofagossomo) (58). Conforme descrito na Figura 2, o Atg7 atua como a ligase E1 ativando as proteínas semelhantes à ubiquitina Atg12 e LC3 (microtubule-associated protein light chain 3). Uma vez ativadas, elas são então transferidas para as proteínas Atg3 e Atg10, que atuam como ligases E2 e promovem a lipidação da LC3 e a conjugação da Atg12 à Atg5, respectivamente. Na sequência, o conjugado Atg12-Atg5 é catalisado pela Atg16 (Ligase E3), culminando na formação do fagoforo juntamente com a LC3 lipidada. Por fim, o elongamento do fagoforo (expansão da membrana), seguida pelo reconhecimento e sequestro dos componentes citoplasmáticos precede a fusão do autofagossomo com o lisossomo para posterior degradação do seu conteúdo por meio das hidrolases ácidas (59).

Dentre as diversas Atgs envolvidas na iniciação, formação e expansão da membrana do autofagossomo, a LC3 é uma das poucas proteínas conhecidas que se mantém ligadas à estrutura após sua maturação. É importante destacar que a forma lipidada da proteína (LC3-II) representa sua forma ativa, ou seja, aquela conjugada à membrana do autofagossomo. Ainda, a LC3-II é degradada pelas hidrolases ácidas junto com o material capturado, podendo também ser um marcador do fluxo autofágico (60).

Apesar de parcialmente não-seletivo, evidências demonstram que o controle de qualidade celular promovido pela autofagia exibe seletividade à degradação de algumas proteínas e organelas. De fato, a ligação da proteína p62 (sequestosome 1) à substratos ubiquitinados pode interagir com a LC3, encaminhando especificamente essa proteína/organela para englobamento pela vesícula autofágica (61). Mesmo fenômeno ocorre por meio da interação entre as proteínas PINK1-Parkin marcando seletivamente as mitocôndrias para serem degradadas pelo lisossomo (62). Este tópico será melhor abordado na subseção seguinte.

Sabendo que a célula muscular esquelética (pós-mitótica) necessita de mecanismos coordenados e eficientes no combate ao estresse induzido pelo acúmulo de proteínas e organelas danificadas (63), a autofagia vem ganhando 
destaque visto que o mau-funcionamento de proteínas lisossomais e o consequente prejuízo na autofagia estão relacionadas à miopatias esqueléticas. De fato, doenças de Danon e Pompe, assim como a miopatia relacionada ao cromossomo $\mathrm{X}$ com excesso de autofagia (XMEA - X-linked Myopathy with Excessive Autophagy) levam à um dano muscular via prejuízos no sistema lisossomal-autofágico (64). Além disso, a inativação músculo específica de genes cruciais para a autofagia leva à uma degeneração miofibrilar contribuindo para a disfunção/atrofia muscular (65).

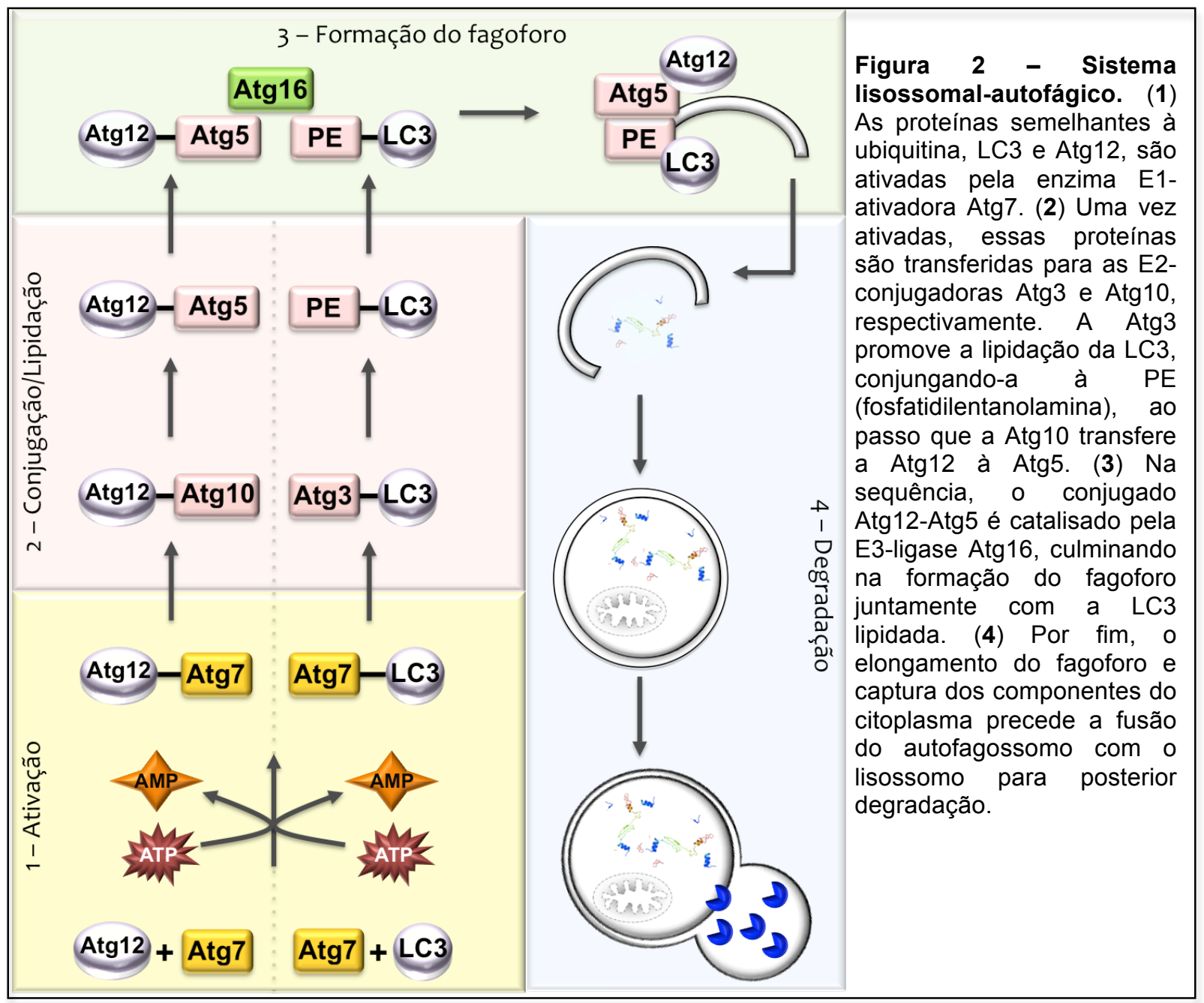

Apesar da degradação via sistema lisossomal-autofágico ocorrer por diferentes formas, esse sistema não degrada proteínas citosólicas como as miofibrilas (66). Entretanto, um aumento na expressão de proteínas relacionadas à autofagia vem sendo reportado na musculatura esquelética atrófica em diferentes condições patológicas $(5,67,68)$, incluindo na denervação induzida por $\mathrm{CCl}(69)$. 
Nesse sentido, uma compreensão mais detalhada do sistema lisossomal-autofágico no quadro de disfunção/atrofia muscular se faz necessário.

\subsubsection{Controle de qualidade mitocondrial (CQM)}

As mitocôndrias são organelas centrais na fisiologia muscular esquelética, sendo a principal fonte de ATP para contração das miofibrilas e um dos principais reguladores da homeostase redox e da morte celular. O CQM está em vigor para assegurar especificamente a função e integridade das mitocôndrias, e pode ser dividido em três grandes níveis de vigilância. O primeiro envolve uma rede integrada de sistemas desintoxicantes capazes de combater a toxicidade mitocondrial mediada por $\mathrm{O}_{2}$ e aldeídos. A segunda linha de vigilância se baseia em proteases e chaperonas responsáveis pela manutenção da proteostase mitocondrial. Ao passo que o terceiro nível, foco deste estudo, envolve o controle do número e da morfologia mitocondrial através de dois processos interligados: dinâmica mitocondrial e mitofagia (Figura 3). Em conjunto esses sistemas bem conservados são capazes de regular o estado redox e o conteúdo, tamanho e número de mitocôndrias (biogênese mitocondrial) por meio de alterações bioenergéticas, bioquímicas e eletroquímicas (8, 41). De fato, falhas no CQM e a consequente disfunção mitocondrial vem sendo implicadas em diferentes patologias (9, 70).

A dinâmica mitocondrial é diretamente mediada pelo equilíbrio entre os processos de fusão e fissão da organela. Conforme demonstrado na Figura 3, a união de duas ou mais mitocôndrias é regulada por duas classes de GTPases mitocondriais: mitofusins 1 e 2 (Mfn1 e Mfn2) e optical atrophy 1 (OPA1), controlando respectivamente a fusão das membranas externa e interna. A fusão mitocondrial é importante pois permite a troca de proteínas, DNA e metabólitos entre diferentes organelas, contribuindo assim para a manutenção da fosforilação oxidativa, do potencial de membrana e do reparo de DNA. Por outro lado, ao originar duas novas mitocôndrias, o processo de fissão auxilia tanto no transporte das mesmas para regiões com maior demanda energética, como na segregação de mitocôndrias disfuncionais para serem encaminhadas para degradação (mitofagia). Esse processo é regulado, majoritariamente, pela GTPase dynamin-related protein 1 (Drp1), que ao translocar-se do citosol para a membrana externa mitocondrial se liga à fission 1 homologue protein (Fis1) efetuando a fissão (71). Ainda, recentemente a 
proteína mitochondrial fission factor (MFF) foi identificada como o receptor dominante para Drp1 na maioria dos tipos de células de mamíferos (72).

Confirmando a importância da fusão mitocondrial para a manutenção da morfologia muscular esquelética, a deleção músculo-específica da Mfn1 e Mfn2 resulta numa profunda atrofia muscular em camundongos, acompanhada de disfunção mitocondrial e acúmulo de mutações no DNA da organela (73). Nesse contexto, mutações nas proteínas Mfn2 e OPA1, além de serem a causa de doenças neurodegenerativas (Charcot-Marie-Tooth Type 2A e Dominant Optic Atrophy, respectivamente), também estão relacionadas com a miopatia esquelética $(74,75)$. Além disso, o aumento na expressão das proteínas que regulam a fissão mitocondrial desencadeia uma redução da massa muscular esquelética, enquanto que o uso de inibidores específicos da Drp1 parece prevenir parcialmente esse fenótipo (76).

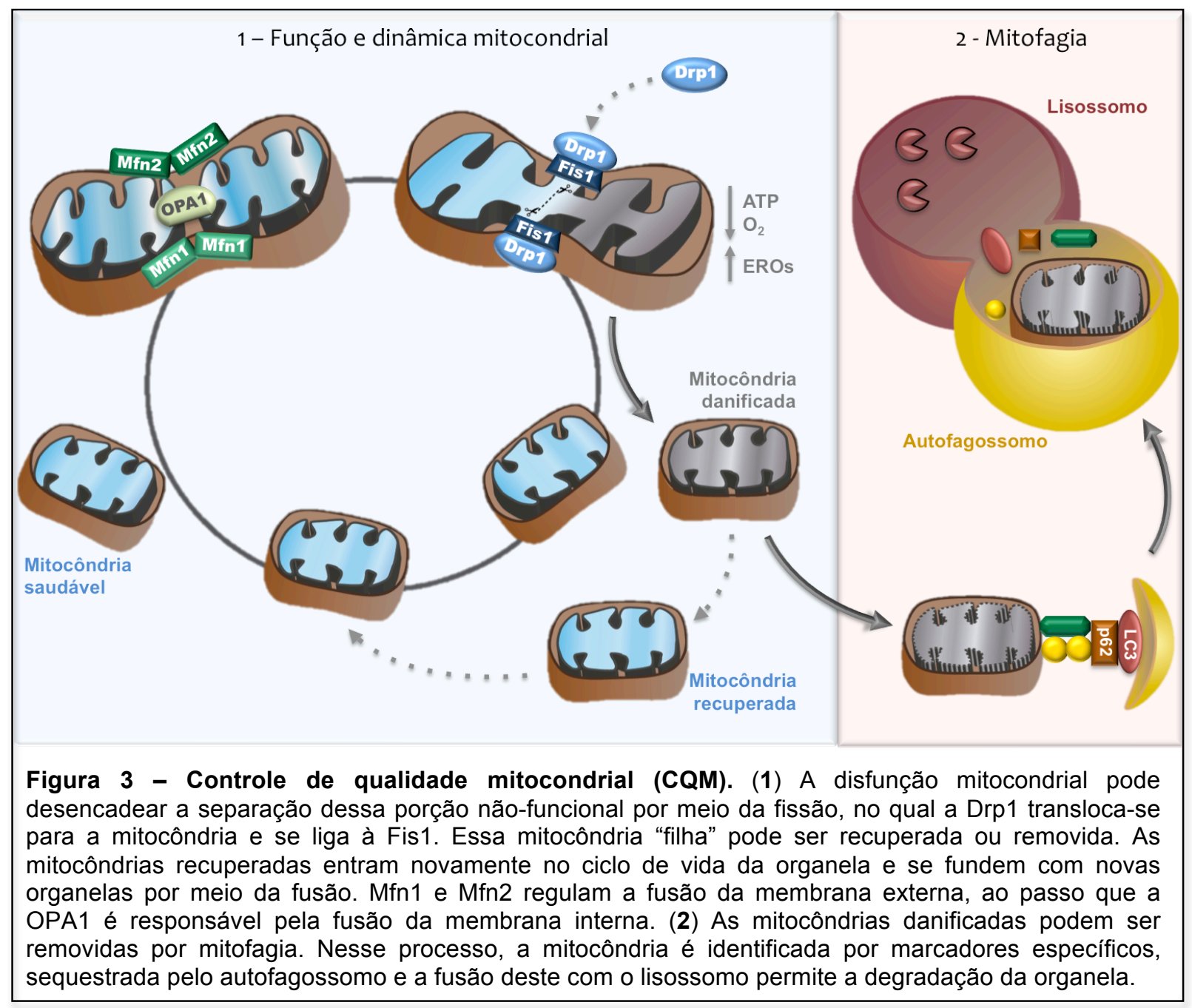


Após o processo de fissão, se a mitocôndria não é reintegrada no ciclo de vida da organela, as mitocôndrias danificadas podem ser encaminhadas para degradação via sistema lisossomal-autofágico, processo conhecido como mitofagia. As mitocôndrias podem tanto ser englobadas diretamente pelo lisossomo num processo denominado microautofagia (77), como podem ser seletivamente marcadas e sequestradas pelo autofagossomo para posterior fusão e degradação no interior dos lisossomo $(78,79)$. A marcação seletiva dessas mitocôndrias ocorre, em sua maioria, pela ação coordenada da proteína PTEN-induced putative kinase (PINK1) e da ligase E3 Parkin de forma dependente do potencial de membrana da organela. Nesse caso, o acúmulo de PINK1 na membrana de mitocôndrias despolarizadas acaba por recrutar Parkin para a organela. Esta por sua vez, é capaz de ubiquitinar substratos que serão degradados pelo proteassoma; ou ainda pode ser identificada por proteínas adaptadoras (Optineurin, NDP52 e p62) que facilitam o reconhecimento e recrutamento das mitocôndrias danificadas para degradação (80). Entretanto, é importante salientar que mecanismos independentes do potencial de membrana mitocondrial também vem sendo descritos (81).

Evidências recentes sugerem que a redução da mitofagia contribui para o acúmulo de mitocôndrias disfuncionais na sarcopenia, atrofia muscular decorrente do envelhecimento. Além disso, a inativação genética do processo autofágico, e consequentemente da mitofagia, resulta em disfunção mitocondrial associada à atrofia muscular $(82,83)$. Por outro lado, a hiperativação da mitofagia via superexpressão de Parkin foi capaz de melhorar a função mitocondrial e atenuar o acúmulo de agregados proteicos na musculatura esquelética de drosófila no envelhecimento (84).

Apesar do papel crucial da ação coordenada entre a fusão-fissão mitocondrial e a mitofagia já ter sido demonstrada em diferentes tecidos, ainda não está claro como as mudanças na morfologia mitocondrial afetam as características morfofuncionais da musculatura esquelética, tanto em condições fisiológicas, como em quadros patológicos. Portanto, parte deste estudo envolveu a avaliação do CQM no quadro de disfunção/atrofia muscular esquelética, com foco na função, biogênese, dinâmica e degradação mitocondrial. 


\subsection{PAPEL DO RECEPTOR $\beta_{2}$-ADRENÉRGICO ( $\beta_{2}$-AR) NA MUSCULATURA ESQUELÉTICA}

Os receptores $\beta$-AR desempenham um papel fundamental na fisiologia cardiovascular, respiratória, metabólica e reprodutiva, motivo pelo qual é o tipo mais estudado entre os receptores AR. Grande parte do conhecimento sobre a sinalização $\beta-A R$ baseia-se em trabalhos conduzidos no músculo cardíaco (85), contudo, nos últimos anos tem sido demonstrada sua importância para o desenvolvimento, crescimento e reparo da musculatura esquelética (86).

A família dos receptores $\beta$-AR é composta por três subtipos, $\beta_{1}, \beta_{2}$ e $\beta_{3}$, que apresentam $70 \%$ de homologia em sua composição de aminoácidos. O músculo esquelético contém uma proporção significativa de receptores $A R$ do subtipo $\beta_{2}$, aproximadamente $90 \%$, e uma pequena parcela do subtipo $\beta_{1}(10 \%)(87)$. A densidade desses receptores é desigual nos diferentes tipos de fibras musculares, no qual músculos oxidativos apresentam densidade duas a três vezes maior comparados à musculatura glicolítica (88). No entanto, o significado funcional desta diferença ainda não é completamente conhecido, já que a resposta a agonistas $\beta$-AR parece ser maior em músculos glicolíticos (89).

Assim como outros receptores $A R$, os receptores do subtipo $\beta_{2}$ são membros da família de receptores acoplados à proteína G (GPCR - Guanine nucleotidebinding $G$ protein-coupled receptor (90)) e sua estimulação ocorre por meio da ação de catecolaminas plasmáticas e de terminais nervosos que estão em contato com as fibras musculares estriadas (86). Sabe-se que esses receptores se acoplam majoritariamente aos subtipos $\mathrm{Ga}_{\mathrm{s}}$ e $\mathrm{Ga}_{\mathrm{i}}$ da proteína $\mathrm{G}$, os quais estão envolvidos, respectivamente, na ativação e na inibição da via clássica de sinalização $\beta_{2}$-AR por meio da adenilato ciclase (AC). Conforme ilustração ao lado e de maneira simplificada, a ligação do agonista ao receptor e consequente ativação da AC converte ATP em adenosina 3',5'- monofosfato cíclico (AMPc), que por sua vez ativa várias moléculas efetoras, dentre elas, a PKA. Além disso, tem sido demonstrado que o subtipo $\beta_{2}$ também é capaz de ativar vias de sinalização independentes do AMPc, no qual o seu acoplamento com o dímero $G \beta y$ da proteína $G$ ativa a via de sinalização

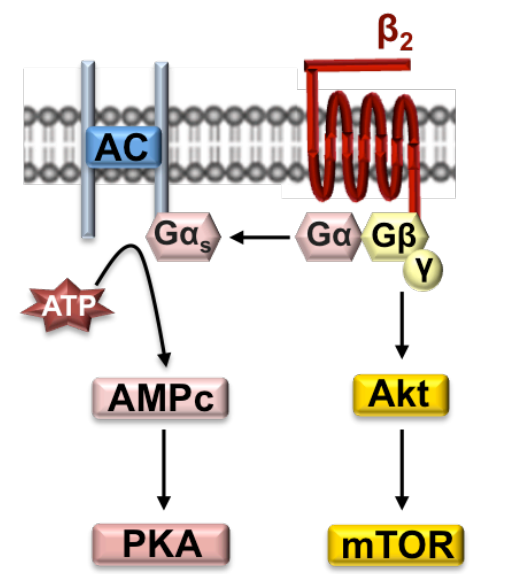


Akt/mTOR, importante reguladora do trofismo muscular (26).

Dentre os principais efeitos da estimulação $\beta_{2}-A R$, destacam-se a hipertrofia muscular e mudança no tipo de fibra, de oxidativa para glicolítica $(I \rightarrow I I)(10)$. Nesse sentido, agonistas $\beta$-AR têm sido utilizados na tentativa de promover o anabolismo, melhorar a produção de força e atuar na regeneração muscular esquelética em diversas situações patológicas como: após trauma grave, em distúrbios neuromusculares, no envelhecimento, na sepse e no câncer. Apesar de diferirem quanto ao tipo de droga, dosagens e tempo de administração, esses estudos confirmam o efeito protetor da estimulação dos receptores $\beta$-AR no trofismo muscular esquelético (86). Entretanto, o pouco conhecimento adquirido até o momento sobre a sinalização intracelular responsável por esse fenótipo baseia-se em trabalhos desenvolvidos no músculo cardíaco (85). Assim como no coração, acredita-se que na musculatura esquelética esta via promova aumento na força de contração muscular, por meio da ativação da PKA, e consequente fosforilação de alvos importantes para a manutenção da função e estrutura muscular. Sabendo que o proteassoma tem sua atividade modulada pela PKA no músculo cardíaco, levantamos a hipótese de que os efeitos benéficos da ativação do receptor $\beta_{2}$-AR no músculo esquelético possa ser mediado, em partes, pelo aumento na atividade catalítica proteassomal e consequente prevenção do acúmulo de proteínas danificadas durante a disfunção/atrofia muscular.

Vale salientar que a ativação $\beta-A R$ também parece exercer efeito sobre a mitocôndria em diferentes tecidos, incluindo o músculo esquelético. Estudos das décadas de 70 e 80 já demonstravam que o bloqueio dos receptores $\beta$-AR é capaz de prevenir as adaptações mitocondriais na musculatura esquelética frente ao exercício, tais como aumento na atividade de enzimas oxidativas e menor liberação de EROs $(91,92)$. Na sequência, foi descoberta a participação dos receptores $\beta-A R$ na biogênese mitocondrial em diferentes tecidos, com merecido destaque para os receptores do subtipo $\beta_{2}(11,93)$. E sabendo que o metabolismo mitocondrial está integrado aos processos de fusão-fissão e de remoção da organela (mitofagia), a literatura atual tenta entender o papel da estimulação do receptor $\beta$-AR também no CQM. Nesse contexto, já foi demonstrado que a PKA é capaz de evitar os exacerbados processo de fissão mitocondrial e mitofagia em modelo celular de Parkinson, resultando numa melhora da função mitocondrial (93). Ainda, o aumento na biogênese mitocondrial advinda da estimulação $\beta$-AR parece ter relação com uma 
maior expressão da Mfn2, proteína envolvida na fusão da organela (94). Entretanto, ainda não existem trabalhos na literatura que investigaram o papel da ativação dos receptores $\beta_{2}$-AR no CQM na disfunção/atrofia muscular esquelética.

Por fim, é importante ressaltar o papel da estimulação $\beta$-AR em outros órgãos, como o coração. A administração sistêmica de agonistas sintéticos dos receptores $\beta$-AR tem implicação no desenvolvimento de hipertrofia cardíaca patológica, além de apresentar eventos adversos relacionados às doenças cardiovasculares $(95,96)$. Visando excluir esses efeitos nocivos para uma futura aplicação clínica, optamos pela utilização de um $\beta_{2}$-agonista de terceira geração altamente seletivo, o Formoterol, cuja maior seletividade (200 a 400 vezes) aos receptores do subtipo $\beta_{2}$ em detrimento ao subtipo $\beta_{1}$ presente no coração vem se mostrando capaz de produzir hipertrofia muscular esquelética com mínimos efeitos no trofismo cardíaco (97). Ainda, é importante destacar que, ao contrário dos $\beta_{2}$ agonistas de primeira e segunda gerações, a adição de uma longa cadeia de carbonos contendo um segundo anel de benzeno confere um início mais rápido e um maior tempo de ação dessa classe de agonistas $(98,99)$.

Nesse estudo utilizamos duas diferentes doses de Formoterol, no qual uma promoveu alterações no trofismo muscular, enquanto que a outra não. Essa estratégia nos permitiu identificar o papel do CQP na regulação da função muscular esquelética, independentemente do trofismo.

O entendimento dos mecanismos celulares envolvidos na remoção de proteínas/organelas danificadas durante a disfunção/atrofia muscular trata de objeto de estudo atual e com grande relevância clínica. Com base na literatura apresentada, levantamos a hipótese de que o prejuízo no CQP acarretaria no acúmulo de proteínas/organelas danificadas e contribuiria de maneira significativa para o agravamento do quadro de disfunção/atrofia muscular esquelética. Acreditamos ainda que a manutenção induzida do CQP seria capaz de amenizar o dano e a disfunção celular do miócito. Baseado nos resultados encontrados no tecido muscular cardíaco, propusemos que a ativação dos receptores $\beta_{2}$-AR na musculatura esquelética seria capaz de aumentar a atividade dos sistemas de degradação (em especial do SUP), resultando na melhora do CQP, e posterior aumento da viabilidade do mioblasto (Figura 4). 


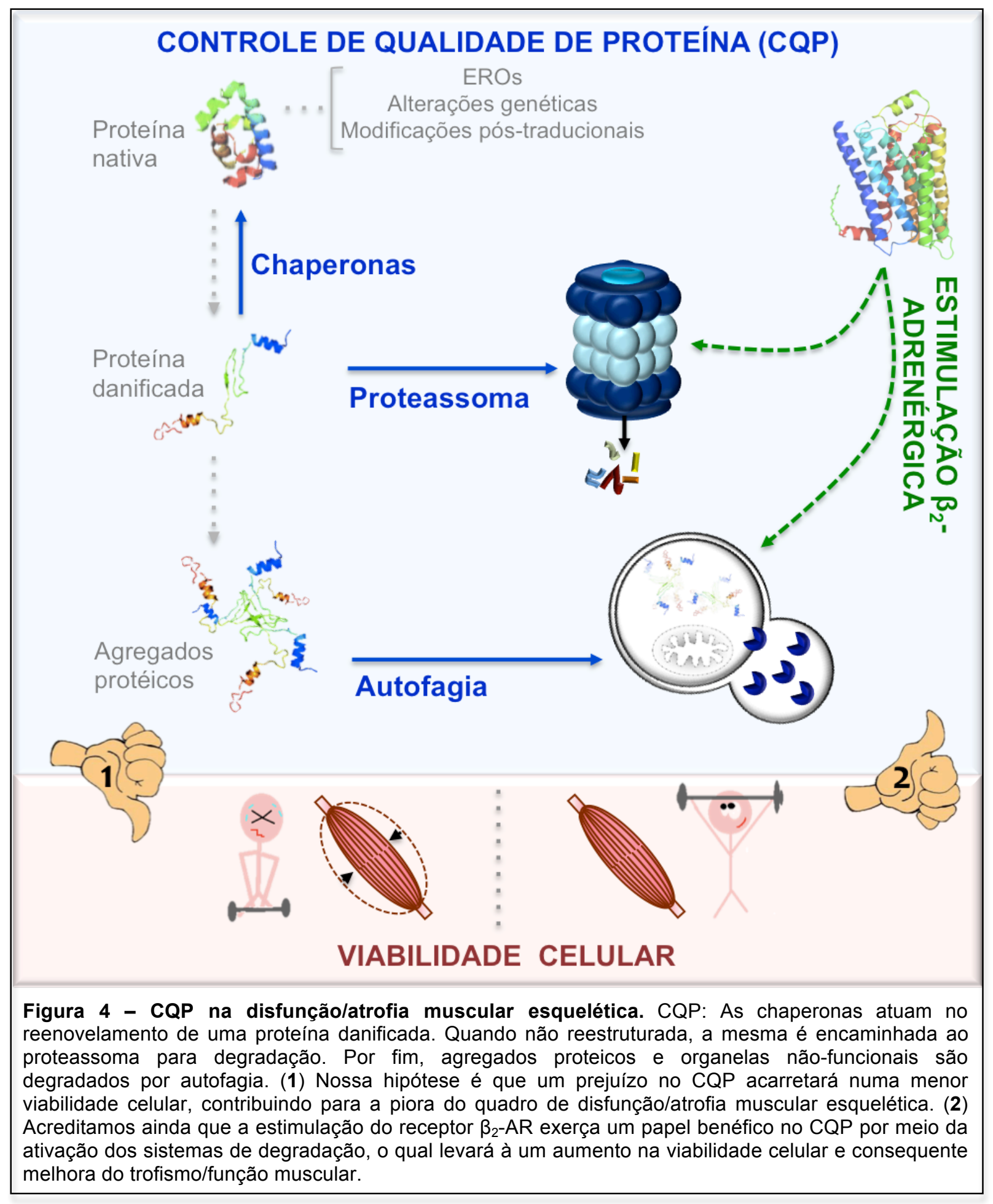




\section{CONCLUSÃO}

Os resultados do presente estudo sugerem uma nova contribuição da via de sinalização $\beta_{2}$-AR no quadro de disfunção/atrofia muscular esquelética, no qual a ativação do receptor $\beta_{2}-A R$ foi capaz de restaurar o insuficiente CQP, contribuindo para a melhora do trofismo e função muscular esquelética. Além disso, nossos resultados evidenciam o papel da via de sinalização $\beta_{2}-A R$ no CQM e reforçam a importância da autofagia como um modulador da morfologia/fisiologia muscular esquelética. 


\section{REFERÊNCIAS*}

1. Cohen S, Nathan JA, Goldberg AL. Muscle wasting in disease: molecular mechanisms and promising therapies. Nat Rev Drug Discov. 2015;14(1):58-74.

2. IHME. GBD Compare Data Visualization. Seattle, WA: IHME, University of Washington; 2016. [Available from: http://vizhub.healthdata.org/gbd-compare ].

3. Schiaffino S, Dyar KA, Ciciliot S, Blaauw B, Sandri M. Mechanisms regulating skeletal muscle growth and atrophy. FEBS J. 2013;280(17):4294-314.

4. Murton AJ, Constantin D, Greenhaff PL. The involvement of the ubiquitin proteasome system in human skeletal muscle remodelling and atrophy. Biochim Biophys Acta. 2008;1782(12):730-43.

5. Mofarrahi M, Sigala I, Guo Y, Godin R, Davis EC, Petrof B, et al. Autophagy and skeletal muscles in sepsis. PLoS One. 2012;7(10):e47265.

6. Wong E, Cuervo AM. Integration of clearance mechanisms: the proteasome and autophagy. Cold Spring Harb Perspect Biol. 2010;2(12):a006734.

7. Romanello V, Sandri M. Mitochondrial Quality Control and Muscle Mass Maintenance. Front Physiol. 2015;6:422.

8. Kotiadis VN, Duchen MR, Osellame LD. Mitochondrial quality control and communications with the nucleus are important in maintaining mitochondrial function and cell health. Biochim Biophys Acta. 2014;1840(4):1254-65.

9. Merlini L, Bonaldo P, Marzetti E. Editorial: Pathophysiological Mechanisms of Sarcopenia in Aging and in Muscular Dystrophy: A Translational Approach. Front Aging Neurosci. 2015;7:153.

10. Yang YT, McElligott MA. Multiple actions of beta-adrenergic agonists on skeletal muscle and adipose tissue. Biochem J. 1989;261(1):1-10.

11. Koopman R, Gehrig SM, Leger B, Trieu J, Walrand S, Murphy KT, et al. Cellular mechanisms underlying temporal changes in skeletal muscle protein synthesis and breakdown during chronic \{beta\}-adrenoceptor stimulation in mice. J Physiol. 2010;588(Pt 23):4811-23.

12. Zong C, Gomes AV, Drews O, Li X, Young GW, Berhane B, et al. Regulation of murine cardiac 20S proteasomes: role of associating partners. Circ Res. 2006;99(4):372-80.

\footnotetext{
${ }^{*}$ De acordo com:

International Comitte of Medical Journal Editors. [Internet]. Uniform requirements for manuscripts submitted to biomedical journals. [2011 Jul 15]. Available from: http://www.nlm.nih.gov/bsd/uniform_requirements.htlm
} 
13. Asai M, Tsukamoto $\mathrm{O}$, Minamino $\mathrm{T}$, Asanuma $\mathrm{H}$, Fujita $\mathrm{M}$, Asano $\mathrm{Y}$, et al. PKA rapidly enhances proteasome assembly and activity in in vivo canine hearts. $\mathrm{J}$ Mol Cell Cardiol. 2009;46(4):452-62.

14. Goldberg AL. Mechanisms of growth and atrophy of skeletal muscle. Muscle Biol. 1972;1:89-118.

15. Wing SS, Lecker SH, Jagoe RT. Proteolysis in illness-associated skeletal muscle atrophy: from pathways to networks. Crit Rev Clin Lab Sci. 2011;48(2):49-70.

16. Glass DJ. Molecular mechanisms modulating muscle mass. Trends Mol Med. 2003;9(8):344-50.

17. Tisdale MJ. Cancer cachexia. Curr Opin Gastroenterol.26(2):146-51.

18. Nicoletti I, Cicoira M, Zanolla L, Franceschini L, Brighetti G, Pilati M, et al. Skeletal muscle abnormalities in chronic heart failure patients: relation to exercise capacity and therapeutic implications. Congest Heart Fail. 2003;9(3):148-54.

19. Callahan LA, Supinski GS. Sepsis-induced myopathy. Crit Care Med. 2009;37(10 Suppl):S354-67.

20. Workeneh BT, Mitch WE. Review of muscle wasting associated with chronic kidney disease. Am J Clin Nutr.91(4):1128S-32S.

21. Harcourt LJ, Schertzer JD, Ryall JG, Lynch GS. Low dose formoterol administration improves muscle function in dystrophic mdx mice without increasing fatigue. Neuromuscul Disord. 2007;17(1):47-55.

22. Caron AZ, Drouin G, Desrosiers J, Trensz F, Grenier G. A novel hindlimb immobilization procedure for studying skeletal muscle atrophy and recovery in mouse. J Appl Physiol. 2009;106(6):2049-59.

23. Muller FL, Song W, Jang YC, Liu Y, Sabia M, Richardson A, et al. Denervation-induced skeletal muscle atrophy is associated with increased mitochondrial ROS production. Am J Physiol Regul Integr Comp Physiol. 2007;293(3):R1159-68.

24. Gopalakrishnan R, Genc KO, Rice AJ, Lee SM, Evans HJ, Maender CC, et al. Muscle volume, strength, endurance, and exercise loads during 6-month missions in space. Aviat Space Environ Med.81(2):91-102.

25. Metter EJ, Talbot LA, Schrager M, Conwit R. Skeletal muscle strength as a predictor of all-cause mortality in healthy men. J Gerontol A Biol Sci Med Sci. 2002;57(10):B359-65.

26. Rommel C, Bodine SC, Clarke BA, Rossman R, Nunez L, Stitt TN, et al. Mediation of IGF-1-induced skeletal myotube hypertrophy by PI(3)K/Akt/mTOR and $\mathrm{PI}(3) K / A k t / G S K 3$ pathways. Nat Cell Biol. 2001;3(11):1009-13. 
27. Proud CG. Signalling to translation: how signal transduction pathways control the protein synthetic machinery. Biochem J. 2007;403(2):217-34.

28. Long YC, Zierath JR. AMP-activated protein kinase signaling in metabolic regulation. J Clin Invest. 2006;116(7):1776-83.

29. Pestronk A, Keeling R, Choksi R. Sarcopenia, age, atrophy, and myopathy: Mitochondrial oxidative enzyme activities. Muscle Nerve. 2016.

30. Andrade $\mathrm{FH}$, Reid MB, Allen DG, Westerblad $\mathrm{H}$. Effect of hydrogen peroxide and dithiothreitol on contractile function of single skeletal muscle fibres from the mouse. J Physiol. 1998;509 ( Pt 2):565-75.

31. Kuwahara H, Horie T, Ishikawa S, Tsuda C, Kawakami S, Noda Y, et al. Oxidative stress in skeletal muscle causes severe disturbance of exercise activity without muscle atrophy. Free Radic Biol Med. 2010;48(9):1252-62.

32. Muller FL, Song W, Liu Y, Chaudhuri A, Pieke-Dahl S, Strong R, et al. Absence of CuZn superoxide dismutase leads to elevated oxidative stress and acceleration of age-dependent skeletal muscle atrophy. Free Radic Biol Med. 2006;40(11):1993-2004.

33. Borisov $A B$, Carlson BM. Cell death in denervated skeletal muscle is distinct from classical apoptosis. Anat Rec. 2000;258(3):305-18.

34. Libera LD, Zennaro R, Sandri M, Ambrosio GB, Vescovo G. Apoptosis and atrophy in rat slow skeletal muscles in chronic heart failure. Am J Physiol. 1999;277(5 Pt 1):C982-6.

35. Patterson C, Ike C, Willis PWt, Stouffer GA, Willis MS. The bitter end: the ubiquitin-proteasome system and cardiac dysfunction. Circulation. 2007;115(11):1456-63.

36. Taylor JP, Hardy J, Fischbeck KH. Toxic proteins in neurodegenerative disease. Science. 2002;296(5575):1991-5.

37. Balch WE, Morimoto RI, Dillin A, Kelly JW. Adapting proteostasis for disease intervention. Science. 2008;319(5865):916-9.

38. Coirault C, Guellich A, Barbry T, Samuel JL, Riou B, Lecarpentier Y. Oxidative stress of myosin contributes to skeletal muscle dysfunction in rats with chronic heart failure. Am J Physiol Heart Circ Physiol. 2007;292(2):H1009-17.

39. Levine RL. Carbonyl modified proteins in cellular regulation, aging, and disease. Free Radic Biol Med. 2002;32(9):790-6.

40. Rando TA, Disatnik MH, Yu Y, Franco A. Muscle cells from mdx mice have an increased susceptibility to oxidative stress. Neuromuscul Disord. 1998;8(1):14-21. 
41. Campos JC, Bozi LH, Bechara LR, Lima VM, Ferreira JC. Mitochondrial Quality Control in Cardiac Diseases. Front Physiol. 2016;7:479.

42. Glickman $\mathrm{MH}$, Ciechanover A. The ubiquitin-proteasome proteolytic pathway: destruction for the sake of construction. Physiol Rev. 2002;82(2):373-428.

43. Amerik AY, Hochstrasser $M$. Mechanism and function of deubiquitinating enzymes. Biochim Biophys Acta. 2004;1695(1-3):189-207.

44. Rivett AJ. The multicatalytic proteinase. Multiple proteolytic activities. J Biol Chem. 1989;264(21):12215-9.

45. Ben-Nissan G, Sharon M. Regulating the $20 \mathrm{~S}$ proteasome ubiquitinindependent degradation pathway. Biomolecules. 2014;4(3):862-84.

46. Busquets S, Figueras MT, Fuster G, Almendro V, Moore-Carrasco R, Ametller $E$, et al. Anticachectic effects of formoterol: a drug for potential treatment of muscle wasting. Cancer Res. 2004;64(18):6725-31.

47. Briguet A, Erb M, Courdier-Fruh I, Barzaghi P, Santos G, Herzner H, et al. Effect of calpain and proteasome inhibition on Ca2+-dependent proteolysis and muscle histopathology in the mdx mouse. FASEB J. 2008;22(12):4190-200.

48. Beehler BC, Sleph PG, Benmassaoud L, Grover GJ. Reduction of skeletal muscle atrophy by a proteasome inhibitor in a rat model of denervation. Exp Biol Med (Maywood). 2006;231(3):335-41.

49. Supinski GS, Vanags J, Callahan LA. Effect of proteasome inhibitors on endotoxin-induced diaphragm dysfunction. Am J Physiol Lung Cell Mol Physiol. 2009;296(6):L994-L1001.

50. Azakir BA, Di Fulvio S, Kinter J, Sinnreich M. Proteasomal inhibition restores biological function of Mis-sense mutated dysferlin in patient derived muscle cells. $\mathrm{J}$ Biol Chem. 2012.

51. Ikemoto M, Nikawa T, Kano M, Hirasaka K, Kitano T, Watanabe C, et al. Cysteine supplementation prevents unweighting-induced ubiquitination in association with redox regulation in rat skeletal muscle. Biol Chem. 2002;383(3-4):715-21.

52. Wing SS, Haas AL, Goldberg AL. Increase in ubiquitin-protein conjugates concomitant with the increase in proteolysis in rat skeletal muscle during starvation and atrophy denervation. Biochem J. 1995;307 ( Pt 3):639-45.

53. Medina R, Wing SS, Goldberg AL. Increase in levels of polyubiquitin and proteasome mRNA in skeletal muscle during starvation and denervation atrophy. Biochem J. 1995;307 ( Pt 3):631-7.

54. Gomes AV, Zong C, Edmondson RD, Li X, Stefani E, Zhang J, et al. Mapping the murine cardiac 26S proteasome complexes. Circ Res. 2006;99(4):362-71. 
55. Bainton DF. The discovery of lysosomes. The Journal of cell biology. 1981;91(3 Pt 2):66s-76s.

56. Bechet D, Tassa A, Taillandier D, Combaret L, Attaix D. Lysosomal proteolysis in skeletal muscle. Int J Biochem Cell Biol. 2005;37(10):2098-114.

57. Choi AM, Ryter SW, Levine B. Autophagy in human health and disease. The New England journal of medicine. 2013;368(7):651-62.

58. Mizushima N, Komatsu M. Autophagy: renovation of cells and tissues. Cell. 2011;147(4):728-41.

59. Cuervo AM. The plasma membrane brings autophagosomes to life. Nat Cell Biol. 2010;12(8):735-7.

60. Klionsky DJ, Abdalla FC, Abeliovich H, Abraham RT, Acevedo-Arozena A, Adeli $\mathrm{K}$, et al. Guidelines for the use and interpretation of assays for monitoring autophagy. Autophagy. 2012;8(4):445-544.

61. Pankiv S, Clausen TH, Lamark T, Brech A, Bruun JA, Outzen $H$, et al. p62/SQSTM1 binds directly to Atg8/LC3 to facilitate degradation of ubiquitinated protein aggregates by autophagy. J Biol Chem. 2007;282(33):24131-45.

62. Youle RJ, Narendra DP. Mechanisms of mitophagy. Nature reviews Molecular cell biology. 2011;12(1):9-14.

63. Zhao J, Brault JJ, Schild A, Cao P, Sandri M, Schiaffino S, et al. FoxO3 coordinately activates protein degradation by the autophagic/lysosomal and proteasomal pathways in atrophying muscle cells. Cell metabolism. 2007;6(6):47283.

64. Sandri M. Autophagy in health and disease. 3. Involvement of autophagy in muscle atrophy. Am J Physiol Cell Physiol. 2010;298(6):C1291-7.

65. Masiero E, Sandri M. Autophagy inhibition induces atrophy and myopathy in adult skeletal muscles. Autophagy. 2010;6(2):307-9.

66. Mayer RJ. The meteoric rise of regulated intracellular proteolysis. Nature reviews Molecular cell biology. 2000;1(2):145-8.

67. Penna F, Costamagna D, Pin F, Camperi A, Fanzani A, Chiarpotto EM, et al. Autophagic degradation contributes to muscle wasting in cancer cachexia. Am J Pathol. 2013;182(4):1367-78.

68. Qiu J, Tsien C, Thapalaya S, Narayanan A, Weihl CC, Ching JK, et al. Hyperammonemia-mediated autophagy in skeletal muscle contributes to sarcopenia of cirrhosis. Am J Physiol Endocrinol Metab. 2012;303(8):E983-93. 
69. O'Leary MF, Vainshtein A, Carter HN, Zhang Y, Hood DA. Denervationinduced mitochondrial dysfunction and autophagy in skeletal muscle of apoptosisdeficient animals. Am J Physiol Cell Physiol. 2012;303(4):C447-54.

70. Ueta CB, Gomes KS, Ribeiro MA, Mochly-Rosen D, Ferreira JC. Disruption of mitochondrial quality control in peripheral artery disease: New therapeutic opportunities. Pharmacol Res. 2017;115:96-106.

71. Liesa M, Palacin M, Zorzano A. Mitochondrial dynamics in mammalian health and disease. Physiol Rev. 2009;89(3):799-845.

72. Otera H, Wang C, Cleland MM, Setoguchi K, Yokota S, Youle RJ, et al. Mff is an essential factor for mitochondrial recruitment of Drp1 during mitochondrial fission in mammalian cells. The Journal of cell biology. 2010;191(6):1141-58.

73. Chen H, Vermulst M, Wang YE, Chomyn A, Prolla TA, McCaffery JM, et al. Mitochondrial fusion is required for mtDNA stability in skeletal muscle and tolerance of mtDNA mutations. Cell. 2010;141(2):280-9.

74. Zuchner S, Mersiyanova IV, Muglia M, Bissar-Tadmouri N, Rochelle J, Dadali EL, et al. Mutations in the mitochondrial GTPase mitofusin 2 cause Charcot-MarieTooth neuropathy type 2A. Nat Genet. 2004;36(5):449-51.

75. Amati-Bonneau $\mathrm{P}$, Valentino $\mathrm{ML}$, Reynier $\mathrm{P}$, Gallardo $\mathrm{ME}$, Bornstein $\mathrm{B}$, Boissiere A, et al. OPA1 mutations induce mitochondrial DNA instability and optic atrophy 'plus' phenotypes. Brain. 2008;131(Pt 2):338-51.

76. Romanello V, Guadagnin E, Gomes L, Roder I, Sandri C, Petersen Y, et al. Mitochondrial fission and remodelling contributes to muscle atrophy. EMBO J. 2010;29(10):1774-85.

77. Yogalingam G, Hwang S, Ferreira JC, Mochly-Rosen D. Glyceraldehyde-3phosphate dehydrogenase (GAPDH) phosphorylation by protein kinase Cdelta (PKCdelta) inhibits mitochondria elimination by lysosomal-like structures following ischemia and reoxygenation-induced injury. J Biol Chem. 2013;288(26):18947-60.

78. Gottlieb RA, Bernstein D. Mitochondrial remodeling: Rearranging, recycling, and reprogramming. Cell Calcium. 2016;60(2):88-101.

79. Shirihai OS, Song M, Dorn GW, 2nd. How mitochondrial dynamism orchestrates mitophagy. Circ Res. 2015;116(11):1835-49.

80. Lazarou M, Sliter DA, Kane LA, Sarraf SA, Wang C, Burman JL, et al. The ubiquitin kinase PINK1 recruits autophagy receptors to induce mitophagy. Nature. 2015;524(7565):309-14.

81. Quinsay MN, Thomas RL, Lee Y, Gustafsson AB. Bnip3-mediated mitochondrial autophagy is independent of the mitochondrial permeability transition pore. Autophagy. 2010;6(7):855-62. 
82. O'Leary MF, Vainshtein A, Iqbal S, Ostojic O, Hood DA. Adaptive plasticity of autophagic proteins to denervation in aging skeletal muscle. Am J Physiol Cell Physiol. 2013;304(5):C422-30.

83. Carnio S, LoVerso F, Baraibar MA, Longa E, Khan MM, Maffei M, et al. Autophagy impairment in muscle induces neuromuscular junction degeneration and precocious aging. Cell Rep. 2014;8(5):1509-21.

84. Rana A, Rera M, Walker DW. Parkin overexpression during aging reduces proteotoxicity, alters mitochondrial dynamics, and extends lifespan. Proc Natl Acad Sci U S A. 2013;110(21):8638-43.

85. Rockman HA, Koch WJ, Lefkowitz RJ. Seven-transmembrane-spanning receptors and heart function. Nature. 2002;415(6868):206-12.

86. Lynch GS, Ryall JG. Role of beta-adrenoceptor signaling in skeletal muscle: implications for muscle wasting and disease. Physiol Rev. 2008;88(2):729-67.

87. Elfellah MS, Dalling R, Kantola IM, Reid JL. Beta-adrenoceptors and human skeletal muscle characterisation of receptor subtype and effect of age. $\mathrm{Br} \mathrm{J}$ Clin Pharmacol. 1989;27(1):31-8.

88. Martin WH, 3rd, Murphree SS, Saffitz JE. Beta-adrenergic receptor distribution among muscle fiber types and resistance arterioles of white, red, and intermediate skeletal muscle. Circ Res. 1989;64(6):1096-105.

89. Ryall JG, Plant DR, Gregorevic P, Sillence MN, Lynch GS. Beta 2-agonist administration reverses muscle wasting and improves muscle function in aged rats. $J$ Physiol. 2004;555(Pt 1):175-88.

90. Fredriksson R, Lagerstrom MC, Lundin LG, Schioth HB. The G-proteincoupled receptors in the human genome form five main families. Phylogenetic analysis, paralogon groups, and fingerprints. Mol Pharmacol. 2003;63(6):1256-72.

91. Svedenhag J, Henriksson J, Juhlin-Dannfelt A. Beta-adrenergic blockade and training in human subjects: effects on muscle metabolic capacity. Am J Physiol. 1984;247(3 Pt 1):E305-11.

92. Ji LL, Lennon DL, Kochan RG, Nagle FJ, Lardy HA. Enzymatic adaptation to physical training under beta-blockade in the rat. Evidence of a beta 2-adrenergic mechanism in skeletal muscle. J Clin Invest. 1986;78(3):771-8.

93. Dagda RK, Gusdon AM, Pien I, Strack S, Green S, Li C, et al. Mitochondrially localized PKA reverses mitochondrial pathology and dysfunction in a cellular model of Parkinson's disease. Cell Death Differ. 2011;18(12):1914-23.

94. Soriano FX, Liesa M, Bach D, Chan DC, Palacin M, Zorzano A. Evidence for a mitochondrial regulatory pathway defined by peroxisome proliferator-activated receptor-gamma coactivator-1 alpha, estrogen-related receptor-alpha, and mitofusin 2. Diabetes. 2006;55(6):1783-91. 
95. Leone M, Albanese J, Martin C. Positive inotropic stimulation. Curr Opin Crit Care. 2002;8(5):395-403.

96. Sleeper MM, Kearns CF, McKeever KH. Chronic clenbuterol administration negatively alters cardiac function. Med Sci Sports Exerc. 2002;34(4):643-50.

97. Ryall JG, Sillence MN, Lynch GS. Systemic administration of beta2adrenoceptor agonists, formoterol and salmeterol, elicit skeletal muscle hypertrophy in rats at micromolar doses. Br J Pharmacol. 2006;147(6):587-95.

98. van Noord JA, Smeets JJ, Raaijmakers JA, Bommer AM, Maesen FP. Salmeterol versus formoterol in patients with moderately severe asthma: onset and duration of action. Eur Respir J. 1996;9(8):1684-8.

99. Jacobsen JR. Third-generation long-acting beta(2)-adrenoceptor agonists: medicinal chemistry strategies employed in the identification of once-daily inhaled beta(2)-adrenoceptor agonists. Future Med Chem. 2011;3(13):1607-22.

100. Bennett GJ, Xie YK. A peripheral mononeuropathy in rat that produces disorders of pain sensation like those seen in man. Pain. 1988;33(1):87-107.

101. Burniston JG, Clark WA, Tan LB, Goldspink DF. Dose-dependent separation of the hypertrophic and myotoxic effects of the beta(2)-adrenergic receptor agonist clenbuterol in rat striated muscles. Muscle Nerve. 2006;33(5):655-63.

102. Ferreira JC, Boer BN, Grinberg M, Brum PC, Mochly-Rosen D. Protein quality control disruption by PKCbetall in heart failure; rescue by the selective PKCbetall inhibitor, betalIV5-3. PLoS One. 2012;7(3):e33175.

103. Grumati P, Coletto L, Sabatelli P, Cescon M, Angelin A, Bertaggia E, et al. Autophagy is defective in collagen VI muscular dystrophies, and its reactivation rescues myofiber degeneration. Nature medicine. 2010;16(11):1313-20.

104. Rolim NP, Medeiros A, Rosa KT, Mattos KC, Irigoyen MC, Krieger EM, et al. Exercise training improves the net balance of cardiac $\mathrm{Ca} 2+$ handling protein expression in heart failure. Physiological genomics. 2007;29(3):246-52.

105. Ingalls CP, Warren GL, Zhang JZ, Hamilton SL, Armstrong RB. Dihydropyridine and ryanodine receptor binding after eccentric contractions in mouse skeletal muscle. J Appl Physiol. 2004;96(5):1619-25.

106. Towbin H, Staehelin T, Gordon J. Electrophoretic transfer of proteins from polyacrylamide gels to nitrocellulose sheets: procedure and some applications. Proc Natl Acad Sci U S A. 1979;76(9):4350-4.

107. Antony JM, van Marle G, Opii W, Butterfield DA, Mallet F, Yong VW, et al. Human endogenous retrovirus glycoprotein-mediated induction of redox reactants causes oligodendrocyte death and demyelination. Nat Neurosci. 2004;7(10):1088-95. 
108. Goodman CA, Mabrey DM, Frey JW, Miu MH, Schmidt EK, Pierre P, et al. Novel insights into the regulation of skeletal muscle protein synthesis as revealed by a new nonradioactive in vivo technique. FASEB J. 2011;25(3):1028-39.

109. Ju JS, Varadhachary AS, Miller SE, Weihl CC. Quantitation of "autophagic flux" in mature skeletal muscle. Autophagy. 2010;6(7):929-35.

110. Anderson EJ, Lustig ME, Boyle KE, Woodlief TL, Kane DA, Lin CT, et al. Mitochondrial $\mathrm{H} 2 \mathrm{O} 2$ emission and cellular redox state link excess fat intake to insulin resistance in both rodents and humans. J Clin Invest. 2009;119(3):573-81.

111. Dimauro I, Pearson T, Caporossi D, Jackson MJ. A simple protocol for the subcellular fractionation of skeletal muscle cells and tissue. BMC Res Notes. 2012;5:513.

112. Sin J, Andres AM, Taylor DJ, Weston T, Hiraumi Y, Stotland A, et al. Mitophagy is required for mitochondrial biogenesis and myogenic differentiation of C2C12 myoblasts. Autophagy. 2016;12(2):369-80.

113. Sin J, Andres AM, Taylor DJ, Weston T, Hiraumi Y, Stotland A, et al. Mitophagy is required for mitochondrial biogenesis and myogenic differentiation of C2C12 myoblasts. Autophagy. 2015:0.

114. Cossarizza A, Baccarani-Contri M, Kalashnikova G, Franceschi C. A new method for the cytofluorimetric analysis of mitochondrial membrane potential using the J-aggregate forming lipophilic cation 5,5',6,6'-tetrachloro-1,1',3,3'tetraethylbenzimidazolcarbocyanine iodide (JC-1). Biochem Biophys Res Commun. 1993;197(1):40-5.

115. Gottlieb RA, Stotland A. MitoTimer: a novel protein for monitoring mitochondrial turnover in the heart. J Mol Med (Berl). 2015;93(3):271-8.

116. Zhang D, Liu M, Ding F, Gu X. Expression of myostatin RNA transcript and protein in gastrocnemius muscle of rats after sciatic nerve resection. Journal of muscle research and cell motility. 2006;27(1):37-44.

117. Dow DE, Cederna PS, Hassett CA, Kostrominova TY, Faulkner JA, Dennis RG. Number of contractions to maintain mass and force of a denervated rat muscle. Muscle Nerve. 2004;30(1):77-86.

118. Chai J, Wu Y, Sheng $\mathrm{Z}$. The relationship between skeletal muscle proteolysis and ubiquitin-proteasome proteolytic pathway in burned rats. Burns. 2002;28(6):52733.

119. Minnaard R, Drost MR, Wagenmakers AJ, van Kranenburg GP, Kuipers H, Hesselink MK. Skeletal Muscle wasting and contractile performance in septic rats. Muscle Nerve. 2005;31(3):339-48.

120. Cornachione AS, Benedini-Elias PC, Polizello JC, Carvalho LC, MattielloSverzut AC. Characterization of fiber types in different muscles of the hindlimb in 
female weanling and adult Wistar rats. Acta histochemica et cytochemica. $2011 ; 44(2): 43-50$.

121. Gazzerro E, Assereto S, Bonetto A, Sotgia F, Scarfi S, Pistorio A, et al. Therapeutic potential of proteasome inhibition in Duchenne and Becker muscular dystrophies. Am J Pathol. 2010;176(4):1863-77.

122. Bodine SC, Latres E, Baumhueter S, Lai VK, Nunez L, Clarke BA, et al. Identification of ubiquitin ligases required for skeletal muscle atrophy. Science. 2001;294(5547):1704-8.

123. Navegantes LC, Resano NM, Migliorini RH, Kettelhut IC. Role of adrenoceptors and cAMP on the catecholamine-induced inhibition of proteolysis in rat skeletal muscle. Am J Physiol Endocrinol Metab. 2000;279(3):E663-8.

124. Harrington LS, Findlay GM, Gray A, Tolkacheva T, Wigfield S, Rebholz H, et al. The TSC1-2 tumor suppressor controls insulin-PI3K signaling via regulation of IRS proteins. The Journal of cell biology. 2004;166(2):213-23.

125. Anderson GP. Formoterol: pharmacology, molecular basis of agonism, and mechanism of long duration of a highly potent and selective beta 2-adrenoceptor agonist bronchodilator. Life sciences. 1993;52(26):2145-60.

126. Wullschleger S, Loewith R, Hall MN. TOR signaling in growth and metabolism. Cell. 2006;124(3):471-84.

127. Zoncu R, Efeyan A, Sabatini DM. mTOR: from growth signal integration to cancer, diabetes and ageing. Nature reviews Molecular cell biology. 2011;12(1):2135.

128. Lynch GS, Hinkle RT, Faulkner JA. Power output of fast and slow skeletal muscles of $\mathrm{mdx}$ (dystrophic) and control mice after clenbuterol treatment. Experimental physiology. 2000;85(3):295-9.

129. Zamah AM, Delahunty M, Luttrell LM, Lefkowitz RJ. Protein kinase A-mediated phosphorylation of the beta 2-adrenergic receptor regulates its coupling to $\mathrm{Gs}$ and $\mathrm{Gi}$. Demonstration in a reconstituted system. J Biol Chem. 2002;277(34):31249-56.

130. Kroemer G, Marino G, Levine B. Autophagy and the integrated stress response. Mol Cell. 2010;40(2):280-93.

131. Mizushima N. The role of the Atg1/ULK1 complex in autophagy regulation. Curr Opin Cell Biol. 2010;22(2):132-9.

132. Luo L, Lu AM, Wang Y, Hong A, Chen Y, Hu J, et al. Chronic resistance training activates autophagy and reduces apoptosis of muscle cells by modulating IGF-1 and its receptors, Akt/mTOR and Akt/FOXO3a signaling in aged rats. Exp Gerontol. 2013;48(4):427-36. 
133. Schwalm C, Jamart C, Benoit N, Naslain D, Premont C, Prevet J, et al. Activation of autophagy in human skeletal muscle is dependent on exercise intensity and AMPK activation. FASEB J. 2015;29(8):3515-26.

134. Zhang X, Chen S, Song L, Tang Y, Shen Y, Jia L, et al. MTOR-independent, autophagic enhancer trehalose prolongs motor neuron survival and ameliorates the autophagic flux defect in a mouse model of amyotrophic lateral sclerosis. Autophagy. 2014;10(4):588-602.

135. Fan J, Yang X, Li J, Shu Z, Dai J, Liu X, et al. Spermidine coupled with exercise rescues skeletal muscle atrophy from D-gal-induced aging rats through enhanced autophagy and reduced apoptosis via AMPK-FOXO3a signal pathway. Oncotarget. 2017;8(11):17475-90.

136. Robin ED, Wong R. Mitochondrial DNA molecules and virtual number of mitochondria per cell in mammalian cells. J Cell Physiol. 1988;136(3):507-13.

137. Satoh M, Kuroiwa T. Organization of multiple nucleoids and DNA molecules in mitochondria of a human cell. Exp Cell Res. 1991;196(1):137-40.

138. MacVicar T, Langer T. OPA1 processing in cell death and disease - the long and short of it. J Cell Sci. 2016;129(12):2297-306.

139. Toyama EQ, Herzig S, Courchet J, Lewis TL, Jr., Loson OC, Hellberg K, et al. Metabolism. AMP-activated protein kinase mediates mitochondrial fission in response to energy stress. Science. 2016;351(6270):275-81.

140. Lippai $M$, Low $P$. The role of the selective adaptor p62 and ubiquitin-like proteins in autophagy. Biomed Res Int. 2014;2014:832704.

141. Palikaras K, Lionaki E, Tavernarakis N. Balancing mitochondrial biogenesis and mitophagy to maintain energy metabolism homeostasis. Cell Death Differ. 2015;22(9):1399-401.

142. Hernandez G, Thornton C, Stotland A, Lui D, Sin J, Ramil J, et al. MitoTimer: a novel tool for monitoring mitochondrial turnover. Autophagy. 2013;9(11):1852-61.

143. Narendra D, Tanaka A, Suen DF, Youle RJ. Parkin is recruited selectively to impaired mitochondria and promotes their autophagy. The Journal of cell biology. 2008;183(5):795-803.

144. Shavlakadze T, Grounds M. Of bears, frogs, meat, mice and men: complexity of factors affecting skeletal muscle mass and fat. Bioessays. 2006;28(10):994-1009.

145. Lecker SH, Solomon V, Mitch WE, Goldberg AL. Muscle protein breakdown and the critical role of the ubiquitin-proteasome pathway in normal and disease states. J Nutr. 1999;129(1S Suppl):227S-37S. 
146. Campos JC, Queliconi BB, Dourado PM, Cunha TF, Zambelli VO, Bechara $\mathrm{LR}$, et al. Exercise training restores cardiac protein quality control in heart failure. PLoS One. 2012;7(12):e52764.

147. Voltarelli VA, Bechara LR, Bacurau AV, Mattos KC, Dourado PM, Bueno CR, Jr., et al. Lack of beta2 -adrenoceptors aggravates heart failure-induced skeletal muscle myopathy in mice. J Cell Mol Med. 2014;18(6):1087-97.

148. Joassard OR, Amirouche A, Gallot YS, Desgeorges MM, Castells J, Durieux $A C$, et al. Regulation of Akt-mTOR, ubiquitin-proteasome and autophagy-lysosome pathways in response to formoterol administration in rat skeletal muscle. Int $\mathrm{J}$ Biochem Cell Biol. 2013;45(11):2444-55.

149. Goncalves DA, Silveira WA, Lira EC, Graca FA, Paula-Gomes S, Zanon NM, et al. Clenbuterol suppresses proteasomal and lysosomal proteolysis and atrophyrelated genes in denervated rat soleus muscles independently of Akt. Am J Physiol Endocrinol Metab. 2012;302(1):E123-33.

150. Goncalves DA, Lira EC, Baviera AM, Cao P, Zanon NM, Arany Z, et al. Mechanisms involved in 3',5'-cyclic adenosine monophosphate-mediated inhibition of the ubiquitin-proteasome system in skeletal muscle. Endocrinology. 2009;150(12):5395-404.

151. Hawkins $C, X u$ A, Narayanan N. Comparison of the effects of the membraneassociated $\mathrm{Ca} 2+/$ calmodulin-dependent protein kinase on $\mathrm{Ca}(2+)$-ATPase function in cardiac and slow-twitch skeletal muscle sarcoplasmic reticulum. Mol Cell Biochem. 1995;142(2):131-8.

152. Agrawal S, Thakur P, Katoch SS. Beta adrenoceptor agonists, clenbuterol, and isoproterenol retard denervation atrophy in rat gastrocnemius muscle: use of 3methylhistidine as a marker of myofibrillar degeneration. Jpn $\mathrm{J}$ Physiol. 2003;53(3):229-37.

153. Conte TC, Silva LH, Silva MT, Hirabara SM, Oliveira AC, Curi R, et al. The beta2-Adrenoceptor Agonist Formoterol Improves Structural and Functional Regenerative Capacity of Skeletal Muscles From Aged Rat at the Early Stages of Postinjury. J Gerontol A Biol Sci Med Sci. 2011.

154. Reid MB. Response of the ubiquitin-proteasome pathway to changes in muscle activity. Am J Physiol Regul Integr Comp Physiol. 2005;288(6):R1423-31.

155. Mitch WE, Goldberg AL. Mechanisms of muscle wasting. The role of the ubiquitin-proteasome pathway. The New England journal of medicine. 1996;335(25):1897-905.

156. Kane RC, Bross PF, Farrell AT, Pazdur R. Velcade: U.S. FDA approval for the treatment of multiple myeloma progressing on prior therapy. Oncologist. 2003;8(6):508-13. 
157. van Hees HW, Li YP, Ottenheijm CA, Jin B, Pigmans CJ, Linkels M, et al. Proteasome inhibition improves diaphragm function in congestive heart failure rats. Am J Physiol Lung Cell Mol Physiol. 2008;294(6):L1260-8.

158. Chacon-Cabrera A, Fermoselle C, Urtreger AJ, Mateu-Jimenez M, Diament MJ, de Kier Joffe ED, et al. Pharmacological strategies in lung cancer-induced cachexia: effects on muscle proteolysis, autophagy, structure, and weakness. J Cell Physiol. 2014;229(11):1660-72.

159. Penna F, Bonetto A, Aversa Z, Minero VG, Rossi Fanelli F, Costelli P, et al. Effect of the specific proteasome inhibitor bortezomib on cancer-related muscle wasting. J Cachexia Sarcopenia Muscle. 2016;7(3):345-54.

160. Smuder AJ, Nelson WB, Hudson MB, Kavazis AN, Powers SK. Inhibition of the ubiquitin-proteasome pathway does not protect against ventilator-induced accelerated proteolysis or atrophy in the diaphragm. Anesthesiology. 2014;121(1):115-26.

161. Korner Z, Durbeej M. Bortezomib Does Not Reduce Muscular Dystrophy in the dy2J/dy2J Mouse Model of Laminin alpha2 Chain-Deficient Muscular Dystrophy. PLoS One. 2016;11(1):e0146471.

162. Baehr LM, Tunzi M, Bodine SC. Muscle hypertrophy is associated with increases in proteasome activity that is independent of MuRF1 and MAFbx expression. Front Physiol. 2014;5:69.

163. Cunha TF, Moreira JB, Paixao NA, Campos JC, Monteiro AW, Bacurau AV, et al. Aerobic exercise training upregulates skeletal muscle calpain and ubiquitinproteasome systems in healthy mice. J Appl Physiol (1985). 2012;112(11):1839-46.

164. Huber JM, Tagwerker A, Heininger D, Mayer G, Rosenkranz AR, Eller K. The proteasome inhibitor bortezomib aggravates renal ischemia-reperfusion injury. Am J Physiol Renal Physiol. 2009;297(2):F451-60.

165. Tang M, Li J, Huang W, Su H, Liang Q, Tian Z, et al. Proteasome functional insufficiency activates the calcineurin-NFAT pathway in cardiomyocytes and promotes maladaptive remodelling of stressed mouse hearts. Cardiovasc Res. 2010;88(3):424-33.

166. Al-Khalili L, de Castro Barbosa T, Ostling J, Massart J, Cuesta PG, Osler ME, et al. Proteasome inhibition in skeletal muscle cells unmasks metabolic derangements in type 2 diabetes. Am J Physiol Cell Physiol. 2014;307(9):C774-87.

167. Gomes AV, Waddell DS, Siu R, Stein M, Dewey S, Furlow JD, et al. Upregulation of proteasome activity in muscle RING finger 1-null mice following denervation. FASEB J. 2012;26(7):2986-99.

168. Klionsky DJ, Abdelmohsen K, Abe A, Abedin MJ, Abeliovich H, Acevedo Arozena $A$, et al. Guidelines for the use and interpretation of assays for monitoring autophagy (3rd edition). Autophagy. 2016;12(1):1-222. 
169. Zhang XJ, Chen S, Huang KX, Le WD. Why should autophagic flux be assessed? Acta Pharmacol Sin. 2013;34(5):595-9.

170. Ikezoe K, Furuya H, Arahata H, Nakagawa M, Tateishi T, Fujii N, et al. Amyloid-beta accumulation caused by chloroquine injections precedes ER stress and autophagosome formation in rat skeletal muscle. Acta Neuropathol. 2009;117(5):57582.

171. Pare MF, Baechler BL, Fajardo VA, Earl E, Wong E, Campbell TL, et al. Effect of acute and chronic autophagy deficiency on skeletal muscle apoptotic signaling, morphology, and function. Biochim Biophys Acta. 2017;1864(4):708-18.

172. Milan G, Romanello V, Pescatore F, Armani A, Paik JH, Frasson L, et al. Regulation of autophagy and the ubiquitin-proteasome system by the FoxO transcriptional network during muscle atrophy. Nat Commun. 2015;6:6670.

173. Jiao J, Demontis F. Skeletal muscle autophagy and its role in sarcopenia and organismal aging. Curr Opin Pharmacol. 2017;34:1-6.

174. Fan J, Kou X, Jia S, Yang X, Yang Y, Chen N. Autophagy as a Potential Target for Sarcopenia. J Cell Physiol. 2016;231(7):1450-9.

175. Wauson EM, Lorente-Rodriguez A, Cobb MH. Minireview: Nutrient sensing by G protein-coupled receptors. Molecular endocrinology. 2013;27(8):1188-97.

176. Wauson EM, Dbouk HA, Ghosh AB, Cobb MH. G protein-coupled receptors and the regulation of autophagy. Trends in endocrinology and metabolism: TEM. 2014;25(5):274-82.

177. Lizaso $\mathrm{A}$, Tan $\mathrm{KT}$, Lee $\mathrm{YH}$. beta-adrenergic receptor-stimulated lipolysis requires the RAB7-mediated autolysosomal lipid degradation. Autophagy. 2013;9(8):1228-43.

178. Wang L, Lu K, Hao H, Li X, Wang J, Wang K, et al. Decreased autophagy in rat heart induced by anti-beta1-adrenergic receptor autoantibodies contributes to the decline in mitochondrial membrane potential. PLoS One. 2013;8(11):e81296.

179. Wang L, Hao H, Wang J, Wang X, Zhang S, Du Y, et al. Decreased autophagy: a major factor for cardiomyocyte death induced by beta1-adrenoceptor autoantibodies. Cell Death Dis. 2015;6:e1862.

180. Aranguiz-Urroz P, Canales J, Copaja M, Troncoso R, Vicencio JM, Carrillo C, et al. Beta(2)-adrenergic receptor regulates cardiac fibroblast autophagy and collagen degradation. Biochim Biophys Acta. 2011;1812(1):23-31.

181. Blei ML, Conley KE, Kushmerick MJ. Separate measures of ATP utilization and recovery in human skeletal muscle. J Physiol. 1993;465:203-22. 
182. Mishra P, Varuzhanyan G, Pham AH, Chan DC. Mitochondrial Dynamics is a Distinguishing Feature of Skeletal Muscle Fiber Types and Regulates Organellar Compartmentalization. Cell metabolism. 2015;22(6):1033-44.

183. Taylor RW, Schaefer AM, Barron MJ, McFarland R, Turnbull DM. The diagnosis of mitochondrial muscle disease. Neuromuscul Disord. 2004;14(4):237-45.

184. Ibebunjo C, Chick JM, Kendall T, Eash JK, Li C, Zhang Y, et al. Genomic and proteomic profiling reveals reduced mitochondrial function and disruption of the neuromuscular junction driving rat sarcopenia. Mol Cell Biol. 2013;33(2):194-212.

185. Beregi E, Regius O, Huttl T, Gobl Z. Age-related changes in the skeletal muscle cells. Z Gerontol. 1988;21(2):83-6.

186. Varanita T, Soriano ME, Romanello V, Zaglia T, Quintana-Cabrera R, Semenzato M, et al. The OPA1-dependent mitochondrial cristae remodeling pathway controls atrophic, apoptotic, and ischemic tissue damage. Cell metabolism. 2015;21(6):834-44.

187. Sebastian D, Sorianello E, Segales J, Irazoki A, Ruiz-Bonilla V, Sala D, et al. Mfn2 deficiency links age-related sarcopenia and impaired autophagy to activation of an adaptive mitophagy pathway. EMBO J. 2016;35(15):1677-93.

188. Hashem SI, Murphy AN, Divakaruni AS, Klos ML, Nelson BC, Gault EC, et al. Impaired mitophagy facilitates mitochondrial damage in Danon disease. J Mol Cell Cardiol. 2017;108:86-94.

189. Miura S, Kai Y, Kamei Y, Ezaki O. Isoform-specific increases in murine skeletal muscle peroxisome proliferator-activated receptor-gamma coactivator-1alpha (PGC-1alpha) mRNA in response to beta2-adrenergic receptor activation and exercise. Endocrinology. 2008;149(9):4527-33.

190. Cribbs JT, Strack S. Reversible phosphorylation of Drp1 by cyclic AMPdependent protein kinase and calcineurin regulates mitochondrial fission and cell death. EMBO Rep. 2007;8(10):939-44. 